\title{
Development and Installation of High Pressure Boilers for Co-Generation Plant in Sugar Industries
}

\author{
Kolar Seenappa Venkatesh ${ }^{1}$, Aashis S. Roy ${ }^{2}$ \\ ${ }^{1}$ Institute of Sugar Technology, G.U.P.G. Center, Bidar, India; ${ }^{2}$ Department of Materials Science, Gulbarga University, Gulbarga, \\ Karnataka, India. \\ Email: venkateshgug@gmail.com
}

Received April $8^{\text {th }}, 2010$; revised May $8^{\text {th }}, 2010$; accepted May $9^{\text {th }}, 2010$.

\begin{abstract}
The sugar cane containing minimum 30\% fiber was referred as bagasse and used the generation of power required for the operation of sugar mill. The bagasse is fired in the boiler for producing steam at high pressure, which is extracted through various single high capacity turbines and used in the process. The installation of high pressure boilers and high pressure turbo-generators has provision for the operation of co-generation plant during the off-season also that enhances the power generation from 9 MW to 23 MW. The annual monetary benefits achieved are Rs. 204.13 million and this was based on cost of power sold to the grid@Rs 2.548 per unit, sugar season of 219 days and off season of 52 days. This required an investment of Rs 820.6 million. The investment had an attractive simple payback period of 48 months.
\end{abstract}

Keywords: High Pressure Boiler, Co-Generation Plant, Sugar Industries, Steam Turbine, Bagasse, Dc Drives.

\section{Introduction}

The Indian sugar industry by its inherent nature can generate surplus power, in contrast to the other industries, which are not only consumers as well as producer of energy. This is mainly due to the $30 \%$ of fiber content in the sugar cane used by the sugar mills. This fibre referred to as bagasse, has good fuel value and is used for generation of the energy required for the operation of sugar mill [1]. The bagasse is fired in the boiler for producing steam at high pressure, which is extracted through various backpressure turbines and used in the process [2]. The simultaneous generation of steam and power commonly referred to as co-generation. Conventionally, the co-generation system was designed to cater to the in house requirements of the sugar mill only. The excess bagasse generated was sold to the outside market [3-5].

In the recent years, with the increasing power 'Demand Supply' gap the generation of power from excess bagasse was found to be attractive. This also offers an excellent opportunity for the sugar mills to generate additional revenue [6-9]. Co-generation option has been adopted in many of the sugar mills, which substantial additional revenue for the mills. This also contributes to serve the national cause in a small way, by bridging the 'Demand supply' gap $[10,11]$.
A 5000 TCD sugar mill in Tamilnadu operating for about 200 days a year had the following equipments:

- Boilers - 2 numbers of 18 TPH, 12 ATA

2 numbers of 29 TPH, 15 ATA

1 number of 50 TPH, 15 ATA

- Turbines-1 number $2.5 \mathrm{MW}$

1 number 2.0 MW

1 number $1.5 \mathrm{MW}$

- Mill drives - 6 numbers 750 BHP steam turbines

1 number 900 BHP shredder turbine

The plant had an average steam consumption of $52 \%$. The power requirement of the plant during the sugarseason was met by the internal generation (Figure 1) and during the non-season from grid (Figure 2) [12,13].

In this paper, we have concentrated to develop and installation of co-generation plant during off-season using high pressure boilers and high pressure turbo-generators.

\section{Experiment}

The plant went in for a commercial co-generation plant. The old boilers and turbine were replaced with highpressure boilers and a single high capacity turbine.

A provision was also made, for exporting the excess power generated, to the state grid. The mill steam turbines were replaced with DC drives. The details of the new 


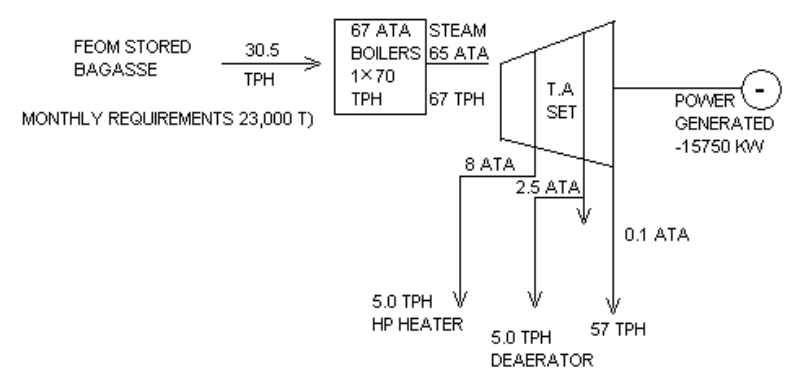

Figure 1. Shows that the energy flow diagram of non-sugar season

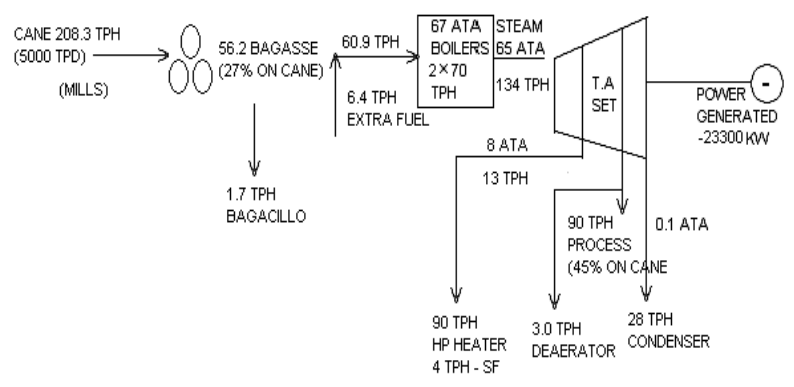

Figure 2. Shows that the energy flow diagram of sugar season

boilers, turbines and the steam distribution are as indicated below:

- Boilers - 2 numbers of 70 TPH, 67 ATA Multi fuel fired boilers.

- Turbines - 1 number of $30 \mathrm{MW}$ turbo- alternator set (Extraction cum condensing type).

- Mill drives - 4 numbers of 900 HP DC motors for mills.

2 numbers of 750 HP DC motors for mills;

2 numbers of $1100 \mathrm{~kW}$ AC motors for fiber.

The two high capacities pressure boilers and a 30MW turbine were installed in place of the old boilers and smaller turbine. While selecting the turbo generator, it was decided to have the provision for operation of the co-generation plant, during the off-season also. This could be achieved by utilizing the surplus bagasse generated during the season, as well as by purchasing surplus bagasse from other sugar mills and biomass fuels such as groundnut shell, paddy husk, cane trash etc. The shortfall of bagasse during off-season was a problem initially. The purchase of biomass fuels from the nearby areas and the use of lignite solved this problem. The entire project was completed and commissioned in 30 months time.

\section{Results and Discussions}

The installation of high-pressure boilers and high-pressure turbo-generators has enhanced the power generation from $9 \mathrm{MW}$ to $23 \mathrm{MW}$. Thus, surplus power of $14 \mathrm{MW}$ is available for exporting to the grid.

The following operating parameters were achieved:

- Typical (average) crushing rate =5000 TCD;

- Typical power generation;

- During season = 5,18,231 units/day;

- During off season =2,49,929 units/day;

- Typical power exported to the grid;

- During season $=3,18,892$ units/day (13.29 MW/ day);

- During off season $=1,97,625$ units/ day (8.23 MW/ day);

- Typical no. of days of operation $=219$ days (season) $=52$ days (off season).

The summary of the benefits achieved (expressed as value addition per ton of bagasse fired) is shown in below Table 1.

The efficient operation of a co-generation system depends on various factors. This has a direct bearing loss in power generation had the power exported to the grid.

Some of these critical factors affecting the power generation (quantified as loss in generation per day) are as follows:

- $1 \%$ drops in bagasse $\%$ in cane: 18300 units;

- $1 \%$ increase in moisture content in bagasse: $6800-$ 10200 units;

- $1 \%$ increase in process steam consumption: 4200 units;

- $1 \%$ drops in crushing rate: $5000-7400$ units;

- 1 hour downtime: 20600 units.

The above figures are based on the following operational parameters:

Table 1. The details of benifits achived after implimentation of high pressure boiler system

\begin{tabular}{cccc}
\hline Parameter & Units & $\begin{array}{c}\text { Previous } \\
\text { status (low } \\
\text { pressure boiler } \\
\text { system) }\end{array}$ & $\begin{array}{c}\text { Present status } \\
\text { (high pressure } \\
\text { boiler system) }\end{array}$ \\
\hline Bagasse quantity & TPH & 1.0 & 1.0 \\
Steam quantity & TPH & 2.1 & 2.2 \\
$\begin{array}{c}\text { Steam pressure } \\
\text { Power generation }\end{array}$ & ATA & 14 & 67 \\
$\begin{array}{c}\text { Extra power } \\
\text { generated }\end{array}$ & $\mathrm{kW}$ & 158 & 382 \\
$\begin{array}{c}\text { Steam quantity } \\
\text { available for } \\
\text { process }\end{array}$ & TPH & & 224 \\
$\begin{array}{c}\text { Steam pressure } \\
\text { available for } \\
\text { process }\end{array}$ & & 2.1 & 2.5 \\
$\begin{array}{c}\text { Steam on cane } \\
\text { ATA }\end{array}$ & & $\mathbf{5 2}$ & \\
\hline
\end{tabular}


- Crushing rate: $5000 \mathrm{TCD}$;

- Steam-bagasse ratio: $1: 2.2$;

- $\mathrm{NCV}$ of bagasse (50\% moisture): $1804 \mathrm{k} \mathrm{Cal} / \mathrm{Kg}$;

- Bagasse content in \% cane: $27 \%$.

\section{Conclusions}

The annual monetary benefits achieved are Rs. 204.13 million (based on cost of power sold to the grid @ Rs 2.548 / unit, sugar season of 219 days and off season of 52 days). This required an investment of Rs 820.6 million. The investment had an attractive simple payback period of 48 months.

\section{REFERENCES}

[1] P. S. Sankarnaraynan, J. G. Evans and C. Dampdaran, "Energy Efficiency in the Sugar Plant Steam and Power Generation," Avant-Garde, Engineers and Consultants Private Limited, Porur, Vol. 1, 2000, pp. 1-6.

[2] A. Ataei, "Modification of Co-Generation Plant in a Sugar Cane Factory for Reduction of Power Deficit," Research Journal of Environmental Science, Vol. 3, 2009, pp. 619-630.

[3] L. Lacrosse and S. K. Shakya, "Clean and Efficient Biomass Cogeneration Technology in Asean," Power-Gen Asia Conference and Exhibition, 2004, pp. 5-7.

[4] C. Damodaran, N. Thirumoorthy and P. Parthasarthy, "Energy Audit in Sugar Industry," Avant-Garde, Engineers and Consultants Private Limited, Porur ,Vol. 1,
2008, pp. 1-6.

[5] R. H. Weed and M. L. Wisdom, "Condensate Considerations in the Development of High Pressure Co-Generation Facilities" BetzDearborn Inc., Trevose, 1998.

[6] Idehara, "Indian Sugar Factories Cogeneration Design Review," Winrock International, Vol. 1, 2004, pp. 1-12

[7] E. Worrell, R. van Berkel, F. Q. Zhou, C. Menke, R. Schaeler and R. O. Williams "Technology Transfer of Energy Science Technologies in Industry," A Review of Trends and Policy Issues, Energy Policy, Vol. 29, 2001, pp. 29-43.

[8] E. D. Larson and R. H. Williams and M. R. L.V. Leal, "Energy for Sustainable Development," Vol. 1, 2001, p. 11.

[9] "Consensus on Operating Practices for the Control of Feed Water and Boiler Water Chemistry in Modern Industrial Boilers," ASME, Vol. 1, 1998.

[10] S. Dunn, "Re: Condensate Contamination Monitors," International Communication, BetzDearborn, 1997.

[11] V. Kirubakaran., V. Sivaramakrishnan, R. Nalini, T. Sekar, M. Premalatha and P. Subramanian, "A Review on Gasification of Biomass," Renew Sustain Energy Review, Vol. 13, 2009, pp. 179-186.

[12] M. Asadi, "Beet-Sugar Hand Book," First Edition, J. Wiley and Sons, Inc., Vol. 1, 2007.

[13] B. W. Lamb and R. W. Bilger, "The Combustion of a Wet Cellulosic Fuel Bed," Sugar Technology Review, Vol. 4, No. 2, 1977, pp. 89-130. 